\title{
KALP HASTALIKLARINDA ANSIZIN ÖLÜMLER
}

\author{
Yazan : Prof. Dr. Adnan özTüreLL
}

Kalp ve damar hastalıkları sebebiyle ansızın ölümler, birden ölüm sebeplerinin başında gelmektedir. Eski müelliflerin bu hususta verdikleri istatistikler, bu günkü yazarlarınkinden daha yüksek orantıdadır. Modern tedavinin bu azalmada rolü mevcuttur $(18,19,26,29,30,31)$.

Kalp ve damar hastalıklarında ansızın ölüm orantısının Richter \% 80, Hofman \% 74, Brighton \% 59.4, Lauren \% 55, Lesser $\%$ 54, Helpern ve Rapson \% 44,9, Weyrich \% 42 olduğunu bildirmişlerdir $(5,18,29,33)$. Ankara Tıp Fakültesi Adlî Tıp enstitüsünce yapılan bir araştırmada, 1957-1962 seneleri arasında ölen ve savcılıkça otopsisi yaptırılan 1017 kişiden 224 ünün ansızın ölüimleri teşkil ettikleri, bunun \% 48.66 sinun (109 kiși) kalp ve damar hastalıklanndan ölduikleri tesbit olunmuştur. Bunların \% 81.65 erkek, $\% 18.35$ kadındır. \% 35.77 köylii \% 64.23 şehirlidir. Șehirlerde kalp ve damar hastalıklariyla ansızın ölüm orantısının fazla olması üzerinde durulacak mühim bir noktadır. Aynı çalışmada 40-60 yaşları arasında \% 43.1 orantısında ani ölüm görüilmisştür.

Memleketimizde kalp ve damar hastalıklarından, ansızın ölen şahısların büyük bir kısmında ölümden önce hiç bir muayene olunmamas1, veya ölümden önceki sağlık durumu hakkında bilgi edinilmemesi sebebiyle, defin ruhsatı verilememekte, bunlar şüpheli ölüm katagorisine sokularak savclikça otopsi yapılmakta, bu sebeple adlî işler fuzulî olarak artmaktadır. Otopsisini yaptığım kalp hastalıkları sebebiyle husule gelen ansızın ölüm vakalarının yarısından fazlasını bu şekil vakalar teşkil etmektedir. Kalp hastalıkJan sebebiyle husule gelen ansızın ölümleri kısaca gözden geçirmek, enteresan müșahedelerimden bahsetmek faydalı olacaktır. 


\section{KALP HASTALIĞI SEBEBIYLE HUSULE GELMİS ANSIZIN ÖLÜM VAKALARI :}

VAKA $1-1961$ senesi ocak ayında, dövüldü̈̆̈i ididasıyla Ankara Mamak Karakoluna müracaat eden 39 yaşındaki A. G, karakoldan muayene için hastaneye gönderilir. Hastanede muayene esnasında birden fenalaşır, kendini kaybeder kısa bir zaman sonra ölür. Bu şahsm otopsisinde düșme, çarpma ve sert bir cisimle vurmak suretiyle husule gelebilen, sol dirsek dıs tarafında mercimek büyüklüğünde sıyrık, sağ omuzda beș kuruş cesametinde bir sıyrlk, bu siyrik kesitinde, derialtinda $3 \times 4$ ebadinda bir ekimoz tesbit ettim. Bunların ölüm tevlit etmeyecek vasıfta oldukları kanaatına vardım. Kalbin 475 gram ağırlığında, hipertrofik olduğunu, sol karınck ön yüzünde eski enfarktüs nedbesi bulunduğunu, mitral ve aort kapaklarında aterom plâkları, koroner damarlarda sertleșme. diğer organlarda konjesyon, ödem olduğunu, ağırlıklarmın arttığını, böbreklerde nefrit hali bulunduğunu müșahade ettim. Ölümün kavga ile ilgisi olmadığı, dolaşım yetersizliği neticesinde husule geldiği kanaatına vardır. Bu vakada şahıs, ölümden önce herhangi bir hastalık belirtisinden şikâyet etmemiștir.

VAKA 2: 1961 senesi mart ayında başkası tarafından döğüldügüi iddia edilen, kavgadan 4 gün sonra normal doğum yapan ve doğumdan 4 gün sonra ölen 30 yaşında, K. Ç. nin otopsisinde; dögüulme ile ilgisi olmayan miyokardit, ancak mikroskopik olarak tesbit edilmiştir. K. Ç. nin vücudunda ölümü tevlit edecek vasıfta dövülmeden mütevellit yara bulunmamıștır. Sol diz dış tarafunda düșme veya sert bir cisimle vurulmadan husule gelebilen bes kurus cesametinde küçük bir sıyrık mevcuttu. Bu vakada kalpteki miyokarditin, doğum sebebiyle daha fazla derecede dolaşım yetersizliği husule getirdiği, ölüme sebep olduğu, döğülme ile ölümün bir ilgisi olmadığı kanaatına vardım.

VAKA 3: 1962 senesi eylül ayında Kayaș'da 35yașında bir șahsın evine meçhul şahıslar hırsızlık maksadıyla girmişler. Bir kavgayı müteakip kaçmışlardır. A. Y. nin bu meçhul şahıslar tarafından gece yatağından kaldırılarak sürüklendiği, dövüldüğ̈̈ ve boğazının sıkılarak öldürüldư̆ğu karısı tarafından iddia edilmişti. A. Y. nin kavgadan, nekadar zaman sonra öldügü kesin olarak tesbit edilememekle beraber, kavgadan sonra bir müddet yaşadı̆̆ı, sabaha 
karşı öldügü tahmin olundu. Otopside sol bacak baldırında $4 \mathrm{~cm}$. $x$ $0.5 \mathrm{~cm}$, sağ bacak bileğinin ön k1smında fasulye büyüklü̈̈̈ünde bir erozyon görüldü. Bunların düşme ve çarpma, sürükleme ile olabileceği fakat ölüme sebep olacak mahiyette travma delili olmadıkları kanaatına vardım. Kalp 350 gram ağırığında, sol karıncık hipertrofik, koronerler ateromlu, sertleşmiș, sağ karıncık arka cidarında eski enfarktüs nedbesi tesbit ettim. Karaciğer, dalak ve böbreklerin büyümüss, konjesyone; akciğerlerin ödemli ve konjesyone, ağrlıklarının artmış olduklarını gördiim. Bu şahsın bir kalp hastası olduğu, tesadüfen kavgayı müteakip öldüğü kanaatına vardım.

VAKA 4: Ankara Çınçn bağlannda bir evde oturmakta olan, 21/2/1963 tarihinde öğleden sonra ölen, ölmeden önce komşusuyla kavga ettiği ve ölümün kavga ile ilgili olduğu iddia edilen, 34 yasında F. Y. adındaki bir kadının otopsisinde; sağ bacak iç tarafında $6 \mathrm{~cm}$. x $3 \mathrm{~cm}$. lik, sol el sirtında 4 adet $0.5 \mathrm{~cm}$. uzunluğunda, birbirine paralel erozyonląr görmüsş, bu erozyonların düșme, vurma, çarpma, sürtünme esnasında husule gelebileceği, kavga esnasında da meydana gelmesinin mümkün oldugu, fakat ölüm tevlit etmeyecekleri, iş güce mâni olmadan birkaç günde iyileşeceklerini tesbit etmiștim. Bu vakada kalbi 425 gr. ağırlı̆̆ıda, hipertrofik, konjesyone, yağlı bulmuş, sol karıncık arka cidarında eski enfarktüs nedbesi, koroner damarların daraldığım, sol karıncık duvarının $2.5 \mathrm{~cm}$. kalınlaștığını, să̆ karıncığın genişlediğini; sağ akciğerin 650 , sol akciğerin 575 gr. ve her iki akciğerin ödemli konjesyone olduklarını, karaciğerin 3000 gr., dalağın 300 gr., sağ böbreğin 275, sol böbreğin 270 gram geldiğini, bütün organlarda, eski bir dolaşım yetersizliğine bağlı belirtiler, bilhassa organlardaki ödem ve konjesyonu önemli derecede bulmuștum. Bu vakada ölüm sebebini, eskiden geçirmiş kalp enfarktüsünün tevlit ettiği dolaşım yetersizliği kabul etmiștim.

VAKA 5: Ankara Yenidoğan semtinde oturan, 6 ay önce bir erkek çocuğa livata yaptığı iddiası sebebiyle, muhakemesi devam eden, 24/4/1963 günii savcılıkça yapılan soruşturmayı müteakkip, saat 16 civarnnda yere düşerek bayılan, bayılmadan sonra Adî Tabibin odasına nakledilen ve kısa bir zaman içinde orada ölen 49 yaşındaki Ş. K. nin ailesi tarafından, bir gün önce Ş. K. nin karakolda dövüldü̈üü ölümün bu döğilmeyle ilgisi olduğu iddia edilmiş ve tarafımdan otopsisi yapılmıștır. Sağ elmacık kemiği üstünde $2 \mathrm{~cm}$. 
$x 1 \mathrm{~cm}$. büyüklüğünde taze ekimoz bulmuș, bunun ölümle ilgisi olmayacağı kanaatına varmıştım. Kalbin $\mathbf{4 2 5}$ gram ağırlığında hipertrofik olduğunu, sol karıncık duvarının $2.5 \mathrm{~cm}$. kalınlaştığını; sağ karıncık duvarının $5 \mathrm{~mm}$. olduğunu, genișlediğini; mitral ve aort kapaklarında müteaddit ve mercimek büyüklüğünde aterom plâkları; damarların skleroze olduklarımı, sol koroner damar başlangıconda, damar kanalının büyük bir kısmın daraltan $2 \mathrm{~cm}$. $\times 1 \mathrm{~mm}$. cesametinde bir aterom plâğı olduğunu, kalp önyüzünde 2 adet eski enfarktüs nedbesi bulunduğunu, diğer organlarm konjesyone olduklarım ağılıklarını arttıklarımı (sağ akciğer 725 gr. sol akciğer 425 gr., karaciğer 1700 gr., dalak 275 gr.), Akciğerlerde ödem bulunduğunu, akciğer zarlarının yer yer göğüs kafesine yapışı bulunduklarını, eski plörit sekeli olduğunu müssahade etmiș, öliimün, dolaşım yetersizliği neticesinde husule geldiği kanaatına varmıștım. Yapılan ankette bu şahsın 1960 senesinde kalp krizi geçirdigi, bir müddet tedavi olduğu, sonra iyileștiği ölmeden önce kalp hastalığına dair bir şikâyette bulunmadığı tesbit olunmuş̦tur.

VAKA 6: 1962 senesinde, bacaklarındaki ağrı şikâyetiyle A.T.F hastanesine yatırlan S. E, hastaneye yatırlddktan 24 saat sonra ölmüștür. Ölümden 7 saat önce komaya girmiș ve şuurunu kaybetmiştir. Şuur kaybından önce, yanında bulunan kardeşine, 10 gün önce N. şehirdeki bir lokantada tanımadığı şahıslar tarafından dövüldügüüï, bu dövülme sonucunda hastalandığını söylemiştir. Yapilan ankette S. E, nun uzun zamandanberi bacaklarmdaki endarterit obliterans'dan (iltihaplı damar tıkanması) muzdarip bulunduğu, bu sebepten ölmeden 5 gün önce N. şehrindeki evinde W. $c$ de, dizüstü yere yıkıldığı, fenalaşıı̆̆ Ankara'ya, müteakkip tedaviler yapilmak üzere nakledildiği tesbit olunmuştur. Otopside sol diz kapağı altında tahminen 4-5 gün önce husule gelmiş yarım elayası büyüklüğünde bir ekimoz buldum. Bu ekimozun dizüstü $W$. $c$ de düşme sonucu husule geldiği kanaatına vardım. Kalp ön yüzünde taze enfarktüs, a. coronaire Sinistra'da (kalp sol kırmızı kan damarı), trombus tıkaç, kalpte hypertrofi, Akciğerlerde ödem ve konjesyon sağ böbrekte findık büyükliuğünde infarktüs, heriki bacak vena safena magna'larında (bacak kara kan damarları) endarterit obliterans müșahade ettim.

Bacaktaki damardan kopan iltihabî parçanın, kalp damarımı tıkamak suretiyle miyokard enfarktüsü husulü ile ölümün meydana 
geldiği kanaatına vardım. Dögülmeyi teyit eden bir bulgu tesbit etmedim. Hasta tarafindan, agoni devrinde heyezanlar esnasında, dövülme șeklinde aslı olmayan beyanda bulunabileceğini ihtimal dahilinde gördüm.

VAKA 7: 1958 senesinde, Ankara Balkehriz bağlarındaki bir kavgadan sonra evine dönen, 41 yaşındaki M. U. birkaç saat sonra ölmuiss ve ailesi tarafından ölümün kavga ve dögülme ile ilgisi bulunduğu iddia olunmuştur. Otopside, dögülmeyi teyit eden en küçük bir belirti bulmadım. Kalbin hipertrofik olduğunu, koroner damarın ateromla daraldı̆̆ı, akciğerlerde ödem, konjesyon ve ağırlıkta artma, diğer organlar ağırlıklarında artma (karaciğer $2300 \mathrm{gr}$. ), böbreklerde nefritö bir hal ve sol böbrek dış yüzünde 4 adet nohut büyüklüğüinde kist, bütün organlarda konjesyon bulunduğunu müșahade ettim. Ölümün dolaşım yetersizliği neticesinde husule geldiği, kavga ile bir ilgisi olmadığı kanaatına vardım.

VAKA 8: 1957 senesinde, Ankara köylerinden birinde, bir düğünü müteakkip, kızın ailesi kapıdan çıkarlarken, damadın ailesi ile münakaşaya tutuşmuşlar. Bu arada damadın annesi, 55 yaşındaki H. B. de münakaşaya karışmış. Basit bir itişme olmuş. Bundan sonra H. B. yere yığılmış ve ölmüss. Hükümet tabibi tarafından yapılan otopside, cebir şiddet belirtisi bulunmamıș. Ölïmün kavga ile ilgili oldugu kabul ve muhakemesi devam etmekte iken, hadisenin T. C. K. 452 inci maddesine girip girmeyeceği sorulmuş, dosya tetkik edilmişti. Şahit ifadelerinden, düğin esnasında H. B. nin, köy dügünü adeti veçhile güreştirildiłi ve bu güreșten sonra münakașa ve itişme olduğu tesbit edildi. H. B. otopsisinde dolașım yetersizliğini gösteren bulgular önemli derecede idi. Ölümün münakașa ve kavga ile ilgili olmadığı, güreşi müteakkip dolaşım yetersizliğinin artması ve kalbin durması neticesinde vukua geldiği kanaatına varildr.

VAKA 9: 1957 senesinde 52 yaşındaki Dr. S. K. basit bir trafik kazasından sonra, diğer şöförü dövmüş, fakat kazayı yapan şöförün Dr. S. K. ye vurmadiğı tesbit olunmuștur. Dr. S. K. bu hâdiseden 1 saat sonra ameliyata girmiș, ameliyatta fenalık gelmiş ve derhal yapılan muayenede miyokard enfarktïsüi teșhisi konmuş, tedavi edilmiş, hadiseden 2 saat sonra gelen ikinci bir kriz sonunda ölmüștür. Dr. S. K. nin otopsisinde mikoyard enfarktüsü bulunmuştur. Koroner damar kanalının ateromla daraldığı tesbit olunmuștur. 
Daralmıs olan koroner damarın, hadise ve ameliyat faaliyeti ile tamamen tıkandığı ve miyokard enfarktüsü tevlit ettiŏi kanaatına varılmıştır. Dr. S. K. nin hayatta iken arasıra göğsüne gelen hafif ağrılardan başka bir şikâyeti olmadığı, kalpteki bulguların mühim bir belirti vermediği anlaşılmıştır.

VAKA 10: 1961 tarihinde tráfik kazası geçiren, kazayı müteakkip İ. S. hastanesine kaldırılan, 18/6/1961 günü ölen, 33 yaşında T. C. isminde bir iş̧̧inin otopsisinde; kalbin 270 gram ağırlığında ve eski bir mikoyardit ihtiva ettiği mikroskopik olarak tesbit olundu. Trafik kazası sonucu vücudun muhtelif yerlerinde sıyrik, ekimoz husule gelmiș, sol bacak uyluk kemiği $1 / 3$ alt kısmundan kirılmıştı. Trafik kazası neticesi husule gelen yaralar ölüm tevlit edecek vasıfta değillerdi. Bu vakada Akciğerlerde trafik kazasından sonra husule gelmiş pnomoni bulundu. Pnomioni her zaman şahsı öldüren bir hastalık değildir. Ölümün trafik kazasından önce mevcut miyokardit (kalp adalesi iltihabı) veya buna inzimam eden trafik kazasından sonra husule gelen pnomoni sebebiyle husule geldiği kanaatına vardım. Bu șahıs hayatta iken miyorkarditten şikâyet etmemiști.

VAKA 11: Konyanın Kulu kazası Y. köyünde 962 senesi mart ayında ölen, 32 yaşındaki $F$. A nın cesedi gömüldükten bir ay sonra, aynı köyden bir şahıs tarafından zehirlenerek öldürüldüğü şekiindeki ihbarı üzerine, mezar açılmış, otopsinin Ankara'da yapılmasina Kulu hükümet tabipliğince lüzum görülmüsstü. Otopside, kalbin $450 \mathrm{gr}$. ağırlı̆̆ında ve hiperırofik olmasından başka patolojik bir bulgu tesbit etmedim. Organlarda da ölüme sebep olacak bir toksik madde bulunmadı. Ölümünün kalb hipertrofisine bağlı, olduğu, hâdisenin bir cinayet olamıyacağı kanaatına vardım. Bu vakada F.A. nın ailesine husumet dolayısıyla, ihbar yapıldığı anlaşıldı. Ölümden sonra hekim tarafından muayene edilmeden cesedin gömülmesi otopsi yapılmak zaruretini doğurmuștur. Bu șekil vakalara sık rastlanmaktadır.

VAKA 12: 1961 senesi temmuz aymda, Ankara, Demirlibahçe semtinde bir evde oturan, 25 yaşında hafifmeşrep A. C.. adında, bir kadın evinde ölü bulunmuștu. Yapılan ankette bu kadının sık sık alkol aldığı, bir gece önce bir erkekle yine içki içtikleri tesbit olundu. Otopside; kalbin $\mathbf{4 2 5}$ gram ağırlığında, hipertrofik konjesyonlu olduğunu, diğer organların da konjesyine ve ağırlıklarının arttığını 
lesbit ettim. (Sağ akciğer 420 gr., sol akciger 450 gr., karaciğer 1980 gr., dalak 190 gr., sağ böbrek 230 gr., sol böbrek 180 gr.). Sağ böbrekte nefrit hali mevcuttu. Organlarda toksik madde bulunmadı. Kanda binde $0.5 \mathrm{cc}$, alkol bulundu. Ölümün, kronik alkolizm ve dolașım yetersizliğiyle husule geldiği kanaatına vardım.

VAKA 13: 1961 senesi eylül ayında Ankara O. G. mahallesindeki bir evin odasında kalan, 60 yaşında, alkolik olduğu bilinen A. A. nın (Erkek), evsahibi tarafından ölmüs olduğu anlaşılır. Birgün önce hiç bir şikâyeti olmıyan bir arkadaşı ile içki içen bu şahsụn ölümü şüpheli görüldưğuinden, tarafımdan otopsi yapılmıştı. Otopside kalbi 570 gr. ağırlı̆̆ında, hipertrofik, konjesyone bulmuş, koroner damarlar başlangıcında ve aortta müteaddit aterom plâkJarı tesbit etmiştim. Bütün organlar konjesyone, akciłgerler ödemli ve konjesyonlu idi (sağ akciğer 650 gr., sol akciğer 605 gr., karaciğer 1480 gr., dalak 150, sağ böbrek 220, sol böbrek 140, beyin 1300 gr.). Böbreklerde nefrit buldum. Kanda binde 5 alkol oldugunu tesbit ettim. Ölümün alkol tesiriyle mevcut dolaşım yetersizliğinin artması ve iflaș neticesinde vukua geldigi, bașka bir zehirlenme olmadığı kanaatına vardım.

VAKA 14: 1962 senesi mayıs ayında 65 yaşında M. H. B. isminde bir emekli albay, birlikte yaşadı̆̆ı kadın ve iki misafiri ile beraber içki içer, misafirler gittikten sonra banyoya girer, orada fenalık gelir kısa bir zamanda doktor dahi çağnlmadan ölür. YapıIan ankette bu şahsın eski bir kalp hastası olduğu, uzun zamandır tedavi gördüğü tesbit edilmesine rağmen nikâhsız olarak bir kadınla yașaması ölümü șüpheli bir duruma sokmuş, otopsi yapılmıştı. Otopside, kalbin 690 gram ağırlığında, hipertrofik yağll, konjesyone olduğunu, ön yüzünde süffüzyon şeklinde kanama, sol karıncık duvarının $2,5 \mathrm{~cm}$. kalınlığında ve sağ karıncı̆̆ın genişlediği, mitral ve aort kapağında ve aortun diğer kısımlarında aterom plâklan oldugưunu, koroner damarların sertleşmiş ve kanallarmın daralmış bulunduklarını müşahade ettim. Sol kanncık ön yüzünde eski enfarktüs nedbesi gördüm. Diğer organların konjesyone ve ağırlıklarının çok arttığını tesbit ettim. Akciğerleri ileri derecede ödemli ve konjesyonlu buldum (karaciğer $2575 \mathrm{gr}$., sol akciğer 840 , să akciğer 1125, dalak 300, sağ böbrek 375, sol böbrek 400 gr.). Kalpten alman kanda binde birbuçuk alkol tesbit olundu. Organlarda başkaca bir zehir bulunmadı. Bu vakada ölüm, eski bir kalp 
hastasınin alkol alması ve sonra banyoya girmesi neticesinde esasen mevcut olan dolaşım yetersizliğinin artmasiyle husule gelmiști.

VAKA 15 : 1962 senesi nisan aymda, karısı ve oğlu ile Ankara posta caddesinde Dr. A. S. ye muayeneye giden, muayeneden birkaç gün önce nefesdarlığı ve çarpıntıdan şikâyet eden, başka bir hastalık geçirmemis olan 60 yaşındaki A. A. ya Dr. A. S. tarafından akciğer filmi çekilmesi tavsiye edilir. Aynı apartmandaki bir röntgen mütehassısına film çektirilir. Filmi Dr. A. S. ye göstermeye geldiği sirada, Dr. A. S. tarafmdan A. A. nm durumunun ağır olduğu ve gittikçe ağırlaş̧ı̆̆ı görülür ve derhal bir hastaneye gitmesi tavsiye edilir. Bu sırada A. A. yere yıkılır, kendini kaybeder. Derhal 2 iğne yapilır, oksijen verilir. Yapılan acil tedaviye rağmen A. A. doktorun muayenehanesinde ölür. Ölüm sebebi kesin teşhis edilemediğinden, doktorun bu ölümde bir hatası olup olmadığınt tesbit için tarafımdan otopsi yapılmış̧ı. A. A. nın ağıılaşması üzerine bir ampul carena ve bir ampul sympatol yapılmușttr. Doktorun tavsiye ve acil tedavi tedbirinde bir hata görmedim.

Otopside; beyni 1575 gram ödemli, konjesyone bir halde; kalbin 440 gr. hipertrofik, konjesyone olduğunu, koronerlerin sertleştiklerini aortada üzeri ülserleşmiş aterosk̉leroz plâkları bulundukların, Akciğerlerde bronşit, ödem konjesyon müșahade ettim. Diğer organlar konjesyone bir halde ve ağırlıkları artmıștı (karaciğer 1650 gr., dalak 315 gr., sağ akciğer 600 gr., sol akciğer 475 gr.). Organlardan alınan parçaların misroskopik muayenesi A. T. F. P. A.E. de yapıldı. Akciğerde staz ve bronșit, kalpte Brown atrofisi; karaciğer dalak, böbreklerde dolaşım yetersizliğinin misroskopik belirtileri tesbit olundu. Bu vakada kalb'de mevcut hastalığa bronșitin inzimamı ile kısa zamanda dolaşım yetersizliğini artırmak suretiyle ölüm olduğu, hâdisenin tesadüfen hekim muayenehanesinde vukua geldiği kanaatına vardım.

VAKA 16: Ankara Altındağ kazası K. köyünden, 20/7/1962 de Ankara hastanelerinden birinde karaciğer kisti ameliyatı olmus ve şifa ile taburcu edilmiş, 65 yașında F. B. ismindeki kadın, ayn klinige 11/9/1962 günï koma halinde gelir ve 9 saat gerekli tedaviden sonra ölür. Bu kadının koma ve ölüm sebebi kesin olarak anlașilmadığından, evvelce yapılan ameliyatla ölümün ilgisi olup olmadığın tesbit için, tarafımdan otopsi yapılmıştı. Otopside; kalbin 500 gram ağırlığında hipertrofik, konjesyone, yağlı olduğunu, sağ 
karıncık genişlemiş, sol karıncık duvan $2.5 \mathrm{~cm}$. kalınłaşmıs, mitral, aorta, triküsbid kapaklarında birçok aterom plâklar bulunduklarnn müşahede etmiştim. Akciğerlerde ödem, konjesyon diğer organlarda konjesyon ve hipertrofi bulmuștum. Sağ akciğer 775 gr., sol akciğer 650 gr., karaciğer 2000 gr., dalak 300, sol böbrek 275 gr., sağ böbrek 120 gr. idi. F. B. ölmeden önce ikindi üzeri yemek yemiş, karnının sol üst tarafına bıçak saplanır gibi ağn hissetmiș, ağn beline ve sırtına yayılmış, nefes darlığı olmuş, kısa bir zaman sonra yüzü morarmıș, komaya girmiș olduğundan bir zehirlenmeden de şüphe olunmuștu. Bu vakada, ölümün kalp yetersizliğine bağlı olduğu, evvelce yapılan ameliyatta hata bulunmadı̆̆ını tesbit etmiştim.

VAKA 17: Adam öldürmekten sanık, A. Cezaevinde bulunan, sar'a tedavisi gören, 40 yaşında olan E. K, 1961 senesi eylül ayında, yalnız kaldığı hapishane hücresinde ölü bulunmuștu. Otopside; kalbin 475 gr. ağırlığında hipertrofik olduğunu, sol karınclk duvarının $23 \mathrm{~mm}$. kalınlaştığını; aorta başlangıcında iki adet mercimek büyüklüğünde aterom plâkları olduklarmı; her iki akciğerin ödemli ve konjesyone bulundukların, sağ akciğerin $700 \mathrm{gr}$., sol akciğerın 550 gr. geldiğini; diğer organlarn konjesyone bir halde ve ağırlıklarının artmıs olduklarını müşahade ettim. Sahsın sar'a krizleri geçirdiğini gösteren bir belirti bulmadım. Ölümün yalnız başına dolaşım yetersizliği veya sar'a krizini müteakkip artan dolaşım yetersiżliği neticesinde vukua geldiği kanaatına vardım.

VAKA 18: 1960 senesi şubat aymda, Ankara Bahçelievler semtinde bir apartman dairesinde, yalnız bașına oturan S. K. isimli, bekâr, 50 yaşında hafifmeşrep bir kadın, komşuları tarafından ölï bulunmuș, sağlı durumu hakkında, bir bilgi edinilememiș, ağız ve burundan hafif kanlı köpüiklü bir sıvı gelmesi, yüzün morumtrak renkte olması, bu kadının boğazı sıkılarak öldürülmesi ihtimalini düșündürmüştui. Otopside, dişta ve içte cebir șiddet asari, boyunda boğaz sıkılmak suretiyle ölümü teyit edecek hiçbir belirti tesbit etmedim. Kalbin 525 gram ağırı̆̆ında, hipertrofik, bilhassa sal kalb cidarının kalınlaşmış olduğunu; koroner damarların sertleştiğini, içinde aterom plâkları bulunduğunu; mitral valvülün sertleştiğini ve üzerinde ülserasyon, kireçlenme olduğunu; akciğerlerde ödem, konjesyon bulunduğunu, sağ akciğerin $625 \mathrm{gr}$., sol akciğerin $720 \mathrm{gr}$., karaciğerin 2825 gr., sol böbreğin 305 gr., sağ böbreğin 260 gr., olduğunu, kalbe bağlı bir dolașım yetersizliği neticesinde ölümün hu- 
sule geldiğini tesbit etmiştim. Bu vakadaki otopsi bulguları mühim buigulardı. Fakat kadının hastalığı hakkında kimseden bilgi edinilememişti. Bu kadının sağlığınds hastalığından kimseye bahsetmemesi veya mevcut belirtilerden fazla rahatsizllk hissetmemesi mümkündür. Bu șekil vakalar nadir değildirler.

VAKA 19: 1962 senesi temmuz aymda Ankara Bağlarderesi civarında, bir yerde ölü olarak bulunan 60 yaşındaki H. K. nin ölümü șüpheli görülmüsstü. Yapılan ankette ölümden önce herhangi bir hastalık bulunduğu tesbit olunamamıştı. Otopside kalbi 575 gram ağırlığında, hipertrofik, konjesyone, yağll, sol karıncık duvarı kaİnlığı $2.5 \mathrm{~cm}$. bulmuştum. Akciğerler ödemli, konjesyone ağırlıkları artmıștı. Diğer organlarda konjesyondan başka patolojik bir bulgu görmedim. Ölümün kalb hipertrofisine bağlı dolașım yetersizliğinden olduğu kanaatına vardım. Bu vakada da șahsın ölmeden önceki sağlık durumu hakkında bir bilgi edinilemedi.

VAKA 20 : 1962 senesi ağustos ayında, U̇. Elçiliğinde 5 gündenberi aş̧̧ı olarak çalışan R. K. isimli 45 yaşındaki adam, anî olarak belirli bir şikâyette bulunmadan, Elçilikte işi başında ölmüş̧tii. Yapılan ankette iki sene önce baş dönmesi, çarpıntı halsizlik şikâyetleri olduğu, M. K. hastanesinde kalbinin biraz rahatsız bulunduğu söylenerek bir müddet tedavi edildiği, bundan sonra hiç bir şikâyette bulunmadığı öğrenilmiștir. Otopside; kalbi 370 gr. ağırlığında, hipertrofik, konjesyone bulmus, mitral ve aort kapaklarında, aorta kavsinde, gö̆üus aortunda aterom plâklan tesbit etmiştim. Akciğerleri ödemli konjesyone, ağırlıkları artmıș bir halde, diğer organlar1 konjesyone ve ağırlıklarının artmıș olduklarını müșahade etmiştim (sağ akciğer 625 gr., sol akciğer 425 , karaciğer 2275 gr., dalak 240 gr., sağ böbrek 270 gr., sol böbrek 245 gr.). Bu vakada zehirlenme olmadığı, ölümün kalbdeki bulgular neticesinde husule geldiği kanaatına varmıştım.

VAKA 21: 1962 senesinde Ankara Bankalarından birinde çalhşan K. M. isminde, 55 yaşlarında bir memur tuvalete girer birdaha çıkmaz. Kapı kırılarak tuvalet açıldığında, bu şahsın ölmüs olduğu görülür. Ölmeden önce hiç bir şikâyeti olmayan bu memurun ölüm sebebi șüpheli görüldüğünden otopsisi Ankara Adlî tabibi ile birlikte yapılmıs, sol karıncık arka duvarında taze enfarktüs tesbit edilmişti. Bu enfarktüsü tevlit edecek mahiyette bulgular kalb ve damarlarda bulunmuştu. Kalbin $\mathbf{4 4 0} \mathrm{gr}$. ağırlığında, hipertrofik, yağlı ol- 
duğu, koroner damarlann sertleşmiş bulunduğu ve içlerinde aterom plâkları bulunduğu görülmüștii.

VAKA 22: 1959 senesinde, Ankara Yenimahalle kazasında 38 yașundaki R. T. gece gelip geçen hafif bir krizden sonra sabahleyin evinde ölür. R. T. nin kansiyle ölmeden önce münakaşa etmiş olması. esasen geçinemedikleri komşu ve arkadaşlarinca bilindiğinden, ölüm şüpheli bir hal alır. Otopside, kalb'de hipertrofi, koroner damarlarda aterom, daralma; aortta ateromlar, karaciğerde büyüme, bulank şişme, yağlanma, hepatit; akciğerlerde, anfizem kanama, böbreklerde ve pankreasta bulanık șişme gözle ve mikroskopik olarak tesbit edildi. Ölümün dolașım yetersizliği neticesinde vukua geldiği kanaatma varıldı. Yapılan ankette, R. T. nin hayatta iken bir şikâyeti, hastalı̆̆ı olmadığı tesbit edildi.

Kısaca özetini verdiğim 22 vakadan 9 unda, $(1,2,3,4,5,6,7$, 8,9 uncu vakalar) ölümle, dövülmenin ilgisi olduğu iddia edilmiştir. Hiç birisinde mevcut kalb hastalı̆̆ının dövülme ile ilgisi bulunmamıştır. 10 uncu vakada trafik kazası belirtileri ölüim tevlit etmeyecek mahiyette ve asıl ölüm sebebinin miyokardit olduğu tes. bit edilmiştir. Onbeşinci vakada ailevî husumet dolayısiyle ölïm, zehirlenme olarak ihbar edilmiștir.

12, 13, 14 üncü vakalar alkol alındıktan sonra kalp hastalı̆̆ı sebebiyle ansızin ölïmii teşkil etmektedir. Bu vakalarda anket yetersizliği ve basit ihtimaller üzerine otopsi yapılmıştır. Alkolden bașka bir zehirlenmeden şüphe edilmiştir.

15 ve 16 incı vakalar kısmen hekimi ilgilendirmektedir. Bu vakalarda anket yeter derecede bilgi vermektedir. Bunların Adlî mahiyet arzetmemeleri gerekirdi.

$17,18,19,20,21,22$ inci vakalarda da anket yetersizliği sebebiyle otopsi yapılmıştır. Bu şahıslardan yalnız birisi evinden hariçte ölmüiștür. 17 inci vaka cezaevinde ölmüştür. 17 ve 19 uncu vakalara bile, gerekli bilgi mevcut olsayd otopsi yapmiya lïzum kalmiyacaktı. 18, 20, 21 inci vakaların, ölümden önce sağlı durumları bilimediği için, otopsi yapılmıştır.

22 vakadan 14 üne, ölümden önceki sağlık durumu hakkında bilgi edinilememesi veya eksik bilgi alınması sebebiyle otopsi yapılmıştır. Adîi makamlar fuzulî yere işgal edilmiştir. Vatandaşın sağliğına ehemmiyet vermesinin, sağlık karneleri tanziminin sağlık sigortaları inkişafının, muayyen aylarda sał̧lik muayeneleri yapıl- 
masının, Adlî işleri büyük bir nisbette azaltacağını, adedi az olan bu vakalar bile göstermektedirler. Vakaları \% 63.64 ü erkek, \% 36.36 sı kadındır. Ölüm 25 - 65 yaşları arasında görülmüş̧tür. 20 - 30 yaș arasında 1, 30-40 yaş arasında 6, 40-50 yaş arasinda $7,50-60$ yas arasında 3,60-70 yaş arasında 5 ölüm görülmüștür. En yüksek nisbet 40-50 yaș arasında olup, \%31-81 dir. Kavga ve dövülmenin ölümle ilgili olduğu iddiası bulunan 9 vaka, 30 ilâ 52 yaş arasındaki ölüıleri teşkil etmektedir.

Vakaların \% 15 i yüksek tahsil ve meslek sahibi şahıslardır. Bunların hiç birisinde ölmeden önceki sağllk durumu hakkında bilgi edinilememesi, veya muayeneye rağmen dikkatli bir şekilde tedavi olunmaması üzerinde önemle durulacak bir husustur.

Kalb hastalıkları sebebiyle ansızın ölüm, kalbin 3 katının perikard (kalb zarı), miyokard (kalb kası), Endokard (kalb iç katı) hastalıkları sebebiyle veya kalb kaslarn yırtılmaları veya fonksiyonel bozukluklarla husule gelebilir. Fonksiyonel șekilde ansızın ölüm halinde, otopsi bulguları bazı vakalarda ölümü kısmen izah eder. Bazı vakalarda ise otopsi belirtisi yeter derecede olmaz veya hiç belirti bulunmaz.

1) PERIKARD HASTALIKLARINA BAGLI ANSIZIN ÖLÜMLER:

Çoğunlukla perikardit ismi verilen iltihaplar ve bunların yapısiklıkları ansızın ölüme sebep olur. Perikardit kalbin yükünï arttırır ve büyütür. Tüberküloza bağlı perokarditte, perikardın her iki yaprağı kalınlaşmıștır. Kalbin yüzünü örten perikard pürtüklü bir hal alır. Perikardın dış yaprağı elâstikiyeti azalmı̧̧ sertleşmiş durumdadır. Adlì mahiyet arzeden perikardit müşahedelerim arasında yoktur. Bu vakalar nadir bulunmaktadir.

2) MIYOKARD HASTALIKLARINA BAĞLI ANSIZIN ÓLÜMLER:

\section{A) KORONER DAMARLARIN HASTALIKLARI :}

Kalbin beslenmesi koroner damarlar yoluyla olur. Koroner damarlar aorta başlangıcından çıkarlar. Sonları birbirleriyle bile- 
şimlidir. Koroner damar hastalıklarında kalbin anî durması ve nekrotik miyokard ramolismanlan (erime) husule gelmektedir.

Klinik belirtiyi doğuran koroner damar tıkanması, fizyolojik şekilde husule gelmiş ise, otopside patolojik belirti görülmez. Vagus siniri çevresel ucu uyarılırsa, koroner damar kan hacmi azalır. Çünkü koronerler daralır. Aksine sempatik uyarmmda koroner damarlar genişler. Bu haller refleks şeklinde cereyan eder. Kanda $\mathrm{CO}_{2}$ artınca koroner damarlar genişler. Bundan dolayı bazı hallerde koroner damarlar spazmı kanalın daralması, bu halin otopside görülmemesi mümkündür. Spazm bir süre devam etmişse, sebep olduğu lezyonlar otopside görülür. Kısmen spazm halinde bazan, koroner damarn diger dalları kalbi besleyebilir. Sol koroner damar kesilmelerinde ölümün mutlaka husule gelmemesi üzerinde durulacak önemli bir haldir. Sol koroner spazm ve tıkanmasi hemen ölüm husule getirmemektedir.

1 - KORONER ARTER TIKANMASI : Önemli bir kalb damarı dolaşımının kesilmesi kalbin çalışmamasına ve ölüme sebep olur. Haberde on sene içinde, 11.000 ansızın ölümden 1075 inin koroner skleroz sebebiyle kalb yırtılmasından; Reuter kalple ilgili 1000 ansızın ölümün 520 sinde koroner sklerozu, 200 inde bu damarların tıkandığını görmüştür. Allen ise 1000 kişiden 58 inde önemli bir koroner arter dalinda skleroz ve bu sebeple ansızm ölüm tesbit etmiştir.

Ölüm, bazan kalbin anguvaz (sıkıntı) şeklinde fonksiyonel bozukluğu veya anjinöz șekilde ağrılardan sonra husule gelir.

Bazı vakalarda, öldürüicù kriz kalb'de o zamana kadar gizli kalmıș hastalığın ilk belirtisi olarak görülür. Bazı hastalarda ise müteaddit krizlerden sonra ölüm olur. Bunlarda bir çok defalar anjin dö puvatrin başlıbașına veya taşıkardi ekstrasistol, kalb yetersizliği ile arter basıncı düş̧mesi, vasat belirli taşıkardi, molleoler (ayak bileği) ödem, efforla gelen nefesdarlığı beraber veya anjin dö puvatrinden sonra, bu belirtilerin takip ettiği krizler görüilür. Bazen eski bir miyokard enfarktüsü bulunur. Ölüm bazan, fizik effordan sonra, genellikle istirahat veya uyku esnasında husule gelir (vaka 18).

Patalojik anatomi bulguları

a) Otopside bir trombus veya embolinin (tıkaç) anî olarak 
koroner damarı veya bu damar dallarından birini tıkadığı görülür. Bouchut'nun bir vakasinda mitral valvülde (sol karıncrkla, sol kulakctk arası kapağ) bulunan bir vejetasyonun (ur) koroner damarı tıkadığı görülmüştür.

b) Koroner damarlardaki lezyon eski ise (koronarit, ateroskleroz v.s.), ölüm; diğer dallardan birinin spazmı veya kalbin anî ve fazla çalışmasıyla provoke olmuş koroner yetersizliğinden ileri gelir. Koroner lezyonu, başlangıç kısımlarda veya arter boyunca devamlı bir şekilde bulunabilir.

\section{2 - MIYOKARD ENFARKTÜSÜ VE KALB ANEVRİZMALA-} RININ YIRTILMALARI :

Kalb damarlarından orta çapta veya küçük olanlardan birindeki tıkanma umumiyetle miyokard enfarktüsünü husule getirir. Enfarktüs kalbin yırtılmasına veya yırtılmadan ansızın ölüme sebep olur. $(1,2,3,11,16)$. Enfarktüs neticesi kalbin yırtılması ile ölüm husule gelen vakalar nâdirdir. Eğer enfarktüs nedbeleşirse ekseriya anevrizma husule gelir. Anevrizmanın yırtılması da ansızın ölüm meydana getirir. Büyük damarların tıkanmasında olduğu gibi küçük damardaki tıkanma da endarteriti (damar içi iltihabı) takiben ekseriya tromboz ve emboli husule getirir. Umumiyetle tıkanan damarın beslediği bölgeden daha küçük bir kısımda nekroz, ramolisman ve kan infiltrasyonu hasıl olur. Böylece miyokard enfarktüsü teşekkül eder (Vaka 6). Başlangıçta șiddetli ağrı görülïr. Diğer belirtiler arteriyel basınç düşmesì, göğüste biran görülüp kaybolan frotman, kalb ritmi bozukluğu ve ateștir. Ansızın ölüm, bu andan sonra olabilir. Kalbin önemli bir kısımı kan infiltrasyonuyla harap olmuş demektir. Ölüm ekseriya daha sonra ve kalbin yırtılmasıyla meydana gelmektedir (5-6).

1 - Nekrozla incelmiș doku mukavemeti azalır, kalb içi basıncına dayanamıyarak yırtılır. Kan perikard 1 doldurur. Kalb d1şmdaki kan kitlesi, kalbi durdurur. Kalbin yırtılması vakalarının üçte ikisinde ventriküller arası çizgiden olur. Atriyum'lar ve sağ ventrikül nadiren yırtılır. Yırtık diuzensiz ve belirli veya az belirli olabilir. Uzunluğu umumiyetle $1-2 \mathrm{~cm}$. dir. Yurtığın dıs kısmı iç kısmından çok defa, daha büyük olur. Ölüm mutlaka hemen ol- 
mayıp ekseriya solunum sistemi ve sindirim sistemi bozukluğu veya anjinöz bir ağn bir kaç saat devam ettikten sonra olur. Ölümden önceki belirtilere göre kalb yırtılmaları aşağıdaki şekillerde siniflandirilir.

a) DISPİNEİK ȘEKLII (FORME DİSPNEİQEU). Bu şekilde ölümden önce nefes darlığı görülür.

b) MIDE - BARSAK \$EKLI (FORME GASTRO-INTESTINALE). Bu şekil belirtileri karın organlarında had bir lezyonu, ülser delinmesini, safra kesesi yırtılmasını, had pankreatiti, karaciğer koliği krizini düşündürïr. Karın ağrıları, kusma görülür.

c) ANJINOZZ ŞEKLİ (FORME ANGİNEUSE) : Göğüste şiddetli ağn husule gelir, arteriyel basınç düşer, perikardiyak bölgede bir an görülen ve sonra kaybolan frotman ve ates olur. Taşıkardi, ekstrasistol sık görülür. Kalb sesleri derinden gelir. Ölüm ekseriya ilk saatlerde olur.

d) KOLLAPS ŞEKLII (FORME COLLAPSUS) : Bu tipte daha çok kollaps tabloya hâkimdir.

2 - Ansızın ölüm enfarktüs yırtılmadan husule gelmişse bunun mekanizması başka türlüdür (Vaka 1). Bazı vakalarda kanama bir bölgeyi tahrip eder ve meselâ interseptum orta kısminda ise, kalb hareketlerinin otomatik fonksiyonu imkânı kalmaz. Bu hal kalb önyüzü enfarktüslerinde nadir değildir. Diğer vakalarda endokardın tahrip olduğu ve kalb içinde husule gelen tromboz'un öldürücü emboli meydana getirdiği görülmektedir. Pulmoner embolinin tevlit ettiği miyokrad enfarktüsï vakaları belli başlı bir gurubu teșkil eder. Bazı vakalarda ise ne eksito-Motor yolda bir lezyon, ne de damarda emboli yoktur. Bu halde ölüm mekanizmasının iza. hı güçleşmektedir.

Kalb anevrizmaları ekseriya miyokard enfarktüsünden sonra husule gelirler. Seyrek olarak kalb yaralarından olurlar. Incelmiş olan kalb duvarı, bir mïddet kalb içi basıncına dayanır ve yırtılmasıyla sonuçlanır (7).

Anevrizma ekseriya perikard içinde yırtılır (14-15). Şahıs olduğu yerde ölür. Bazan perikard yapışıklıkları yırtılmaya mâni olabilir. Bazan anevrizma içindeki plhtı yerinden ayrılır. Valvülü veya büyük bir damarı tıkayabilir. Bazı vakalarda ölüm, kalb anevrizmasiyla ilgisi bulunmayan sebeplerle meydana gelir (17). 
MIYOKARD ENFARKTÜSÜ OTOPSİ BULGULARI : Enfarktuislü bölge kirli sarı renkte ve etrafı koyu kırmızı bir sınırla çevrilidir. Yumuşak ve kolay yırtılır kıvamdadır (vaka 21). 24 saat sonra kuru ve etrafından daha parlak, 48-72 saat sonra daha çok kuru ve gevrek bir kıvamda olur. 4 gün sonra enfarktüs çevresindeki koyu kırmuzı sınır sarımtırak bir renk alır. 6-8 gün sonra enfarktïs sahası sarı renk alır. 8-10 gün sonra bu yer çöker ve daha çok sararır, çok yumuşar ve incelir. $3-4$ hafta sonra histiyosit ve retikulum hücrelerinin çoğgalmasıyla granülâsyon başlar, sarı bölgenin etrafında, belirli bir kırmızı morumtrak sınır husule gelir. 5-6 hafta sonra enfarktüs bölgesi granülâsyon dokusu ile tarnamen kaplanarak kırmızı renk alır. 2 - 3 ay sonra bu granülâsyonlu bölge, kollogen lifleri fazla ve bağ dokusu hâkimiyeti olan bir șekilde nedbeleșerek, sert sedefî bir renk alır (vaka 2, 4, 5, 10, 17).

MIYOKARD ENFARKTÜSÜ KOMPLIKASYONLARI : Trombüsler kolayhlkla husule gelirler. Böbrek, dalak, beyinde embolileı yaparlar. Kalb duvarı incelemesinde yırtılma husülü daha önce anlatılmıştır. İncelen kalb duvarnnda anevrizma olabildiğini, bunların da yırtılarak ansızın ölüm yapabildiğinden de bahsedilmiștir.

B) KALB KASLARI ILTIHABI, MIYOKARDIT (MYOCARDİTE) :

Miyokarditler müzmin ve had olmak üzere iki șekilde görülürler ve her iki şekilde de ansızın ölüm husule gelir (vaka 2, 10).

1 - MÜZMIN MIYYOKARDITT (myocardit cronique) : Ansızın ölümü miyokardite bağlamak için, kalbin önemli bir bölgesinde bu afeti tesbit etmek lâzımdır. Kalb otomatik hareketlerle çalıșır. $\mathrm{Bu}$ harekete mâni olacak bir bölgede miyokardit olması ansızın ölüm bakımından çok önemlidir $(8,9,10,27)$.

Kalb'de kas kasılmasıla, kan harekete getirmeye mahsus kaslardan başka özel kas sistemi vardır. Buna kalbin otonom sistemi denir. Uyarımın doğmasına ve iletilmesine yarar. Özel kas lifleri; sarkoplazmadan zengin, darca ve enine çizgilerin iyice belli olmastyla ayrılır. Bu sistem, Keith - flack düğümüyle başlar. Düzenli ve devaml uyarm Keith-Flack düğümünden (V. Cava Superior ve sağ atrium sınırında, sülküs terminaliste, pericard altın- 
da) doğar ve Atriumlara yayllarak Aschoff-Tavara veya atrio-ventriküler düğüme gelir. Bu dügüm Keith-Flack dügüüüinden biraz daha büyüiktiir.

Aschoff-Tavara düğ̈ümü atriyumlar arasındaki septumun alt kısmında, triküspidin orta yaprağının yukarısında ve interventriküler semptomun hemen üstündedir. Sol yüzü aort orijinil ile temasta sigmoid arka valvülün biraz gerisindedir. Sał yüzü yağlı ve birkaç kas fibriliyle endokardın triküispid halkasından ayrılır. Aschoff-Tavara düğümü his hüzmesine gider. Arkadaki irtibatı, kas fibrilleri sağlar. His demeti, interventriküler semptuma girer ve septum membranaceum'un altında iki dala ayrılır. Bu dallarda gittikçe küçük dalcıklara ayrılarak, ventriküllerin iç satıhlarını ał gibi kaplar purkinje sisteminde sonlanirlar.

Kaslara uyarımı ulaştıran pürkinje hücreleridir. Normal olarak Keith - Flack dügüumünden kalkan uyarım kalbi harekete getirir. Fakat bu kısmının harabiyeti kalbin durmasına sebep olmaz, zira daha alt yol ventriküllerin hareketlerini sağlar. Kalbin çalışması için asıl elzem olan Interseptumdaki kısımdır. Bu kısım atriumlar ve ventriküller dıș kısmından daha önemli bir şekilde ansızın ölümde rol oynar.

Miyokardın enflamatuvar (iltihabı) veya dejenerativ lezyonlarmın ansızın ölüm tevlidi, bulundukları bölgeye bağlı olduklar tezi, bu günün hâkim fikridir. Bu durumun özel halleri de mevcuttur $(22,23)$.

MÜZMIN MIYOKARDITLE BİRLIKTE OTOPSIDE GÖUÜLEN BELIRTILER :

a) KALB HİPERTROFISI :

Umumiyetle kalb kaviteleri genişlemeleriyle beraber kalbin bir kısmının veya tamamını hipertrofisi görülür (Vaka 2-10).

Sol ventrikül duvan normal kalınlığı $12 \mathrm{~mm}$. sağ ventrikül 5 $\mathrm{mm}$. kalb ağırlı̆ıı 300 gr. dır. Kalb hipertrofisi yanında aort ve pulmoner valvül stenozu, akciğerlerin yaygın sklerozu, perikard yapı\$̧klığı bulunur. Hipertrofi ekseriya yalnız arter tansiyonu yüksekliğine veya kronik nefritle beraber olan hipertansiyona bağl dur (20). 
b) Kısmen veya tamamen kalb kaviteleri genișlemesi görülür Bilhassa atriyumlar ve sağ ventrikül genişlemesi müşahade edilír

Karaciğer, böbrek ve akciğerlerde ekseriya konjesyon bulunur (12-13). Kalb kaviteleri genişlemesi daha önce anlatılan hallerin bir neticesidir. Pulmoner arter embolisi, had akciğer ödemi, valvül lezyonları da konjesyona sebep olurlar. Konjesyon başlıbaşına da meydana gelmiş olabilir. Fizik efforla kalbin fazla çalı̧̧ması halinde konjesyon husülü mümkündür. Fakat mutlaka meydana gelmesi şart değildir.

MIKROSKOPİK MUAYENE : Kronik miyokardit lezyonları, emflamatuvar odak, sklerozlu bir sınır, kas lifleri arasında yağlanma, kronik endarterittir.

Miyokardit esnasinda ve genel olarak kardiyopatilerde kalbin durması iki șekilde olur (21). Bunlardan birisi ansızın diğeri kısa bir fibrillasyondan sonra görülür. Ansızın durma Adam-Stokes sendromunu müteakkip olur. Hasta başdönmesi; senkop, epilepsi krizi gibi ihtilâçlarla yere yuvarlanır ve ölür. Fibrillâsyon sonunda ekseriya taşıkardi krizi veya Adams-Stoke sendromu sonucu senkop ve ölüm husule gelir. Ölümden sonra bir belirti görülmez.

MIYOKARDİT ŞEKłLLERI : Miyokarditis pürölenta, miyokarditis Romatika, Miyokarditis entertitiyalist kronika, Miyokarditis paranşimatoza, Miyokarditis sifilitika, Miyokarditis fitizika'dır.

2 - HAD MIYOKARDIT (MIYOKARDITE AİGUE) : Tifo, difteri, kızıl, had mafsal romatizması gibi ateșli hastalıklarda, ateşli devrede veya nekahat esnasında ansızın ölüm görülür. Bunlarda ölümden önce kalbin iletim, uyarm ve kontraksiyon sisteminde bozukluklar husule gelir (32).

Otopside yeni miyokardit lezyonlan bulunur. Ölüm bazan hakikaten ansızın, ekseriya kollaps devresinden birkaç dakika veya saatler sonra olur. Otopside, kalb genişlemiș, yumușak, sarı renktedir. Yüzeyinde ekimozlar görülür. Mikroskopik olarak miyokard'da yaygin veya odaklar halinde lezyonlar bulunur. Lezyona uğrayan kas liflerinin enine çizgileri kaybolmuș, protoplazmaları granülo, yağll, hiyalinli ve vaküollüdür. Bă̆ dokusu konjesyonlu ve ödemlidir. Damar duvarları lezyonlan olarak, ekseriya küçük venlerde tromboz göruilür. Küçük damarlar lökositlerle çevrilir. Romatizmal miyokarditte aşof nodülleri vardır. 
Bazı had miyokardit vakalarındä ölüm, barsak delinme veya kanamasyyla, dura mater (beyin zar1) sinüsü trombo flebitiyle olur. Had miyokardit vakalarında muiakkak ölüm olmaz.

\section{C) KALBİN YAGLLANMASI :}

Kalb yağlanmasında ansızın ölüm olabilir. Kalb üstündeki yağ tabakasının kalınlığı yarım santimetreyi geçer. Bütün kalb üstü yağla kaplanır. Bazan sol kenar ve sol vetrikül arka yüzünde yą̆lanmá olmayabilir. Yağlanma miyokard hüzmeleri arasında ve endokard'da olabilir.

Hayatta iken belirli bir bulgu görülmez. Şișman şahıslarda normal sayılan nefes darhı̆̆ı, oburlarda sık görülen sindirim bozukluğu sebebiyle husule gelen ekstrasistoller, miyokarditin kalb yetersizliği, valvül sklerozları, aort ateromu, koroner ateromu, hipertansiyon ekseriya yağlanma ile birlikte olur. Ansızın ölümde bu sebeplerin de rolü vardır. Yalnız yağlanma ile ölüm nadirdir.

\section{D) KALB BÜYÜMESI, HİPERTROFİ (HYPERTHROPHİE);}

Kalb hipertrofisinde kalb büyür, kalınlaşır, ağırlı̆̆ı 2 misli veya daha fazla artabilir ( 2 ve 10 uncu vaka hariç bütün vakalarda). Miyokard serleșir. Bazan kalb duvarının bir kısmı, bazan yalnız papiller kaslar ve trabeküller hipertrofi olur. Sol kalb hipertrofileri arteriyel basınç yüksekliğinde, valvül hastalıklarında, aort anevrizmalarında, gebelikte görülür. Sağ kalb hipertrofileri anfizem, müzmin bronșit, valvül hastalıkları, kifoskolyoz, plevra yapıșılarında husule gelir. Kalb hipertrofileri valvül yetersizliği sonucu, genişleme ile beraber olursa exantrique, böbrek sklerozu neticesi husule gelirse Consentrique şekilde göriilür $(24,25)$.

\section{E) ORİKÜLER YETERSIZLIIK VE ARİTMI KOMPLET (INSUFFISANCE AURICULAİRE ET ARYTMIE COMPLETE) :}

Bir çok vakalarda oriküler (kalb kulakcığı) yetersizlik kalbin ilerleyici ve tam yetersızliği serbeplerinden birisidir. Klinik belirti 
aritmi komplettir. Basit asistoli neticesi, organlarda konjesyon, deri altında ödem, taşikardi, vücut boşluklannda epanşman husule gelir. Oriküler yetersizlik nadir bulunur ve mutlaka ansızın ölüm olmaz. Otopside sol orikül ekseriya genişlemiș bulunur. (vaka 4, 5) Anevrizma gibi bir durumda göruilebilir.

\section{F) SOL VENTRIKÜL (KARINCNK) YETERSİZLIĞI (INSUFFISANCE VENTRICULAIRE GAUCHE) :}

Sağ ventrikülde herhangi bir bozukluk olmadan sol ventrikül vetersizleșebilir (vaka 1, 3, 5, 11, 12, 13). Aort darlığı ve yetersizliğinde sol ventrikül önce hipertrofiye, sonra dilâte olur. Bazan mitral lezyonu, basit kalb hipertrofisi, sol ventrikül enfarktüsii, hipertansiyon, nefrit kroniklilerde sol ventrikül büyür. Otopside sol kalb cidarı belirli bir şekilde kalınlaşmıştır. Hipertansiyonlu Braytik hastalıklarında kalb ağırlığı 700 gramı bulur.

Sol ventrikül yetersizliği farkedilmiyen birkaç belirti verir veya yanlış anlaşılan ve şahsın mühim bir hastahğı olmadığını zannettiren taşikardi, ekstrasistol, dispine deffort gibi bulgular olabilir (Vaka 15, 16).

Anjin dö puvatrin ve had akciğer ödemi mühimdir. Anjin dö puvatrin koroner lezyonlarında olanla hemen hemen aynıdır. Ansızın ölüm birinci kriz esnasında olabilirsede umumiyetle daha geç görülür. Had akciğer ödeminden birkaç gün veya hafta önce ekseriya gece dispineleri olur. Had akciğer ödeminde alveoller, birden kan serositesiyle dolar. Hasta solunum yollarını ve akcigèerleri dolduran sıvıyı dıșarıya atmak için boş yere çabalar. Serosite ve hava karışığı öksürük doğurur. Aksenin başlangıcında ağızda köpük olur. Ciddi bir tedavi yapılmazsa șahıs birkaç dakikada ölür. Otopside akciğerlerden kanlı köpüklii bir sıvı geldiģi görülür (Vaka 20, 21).

\section{G) TAM KALB YETERSIZLIGI (INSUFFICANCE TOTALE) :}

Kalbin tam yetersizlił̧i, asistoli, kalb yetmezliği şeklinin en çok görülenidir. (Vaka 17, 18). Pek çok sebebi vardır. Bunlar arasında miyokard enfarktüsü, aort orijinli kalb bozuklukları, peri- 
kard yapışıklıkları valvüler endokarditler ençok görülenleridir. Belırli bir şekilde seyreden asistolinin Adlî Tıp bakımından büyük bir ehemmiyeti yoktur. Asistoli bazan hızlı seyirli gelișim gösterir. Birkaç saatte gelişip ölüme sebep olabilir ve genç şahıslarda çok fazla fizik faaliyetten sonra bu șekil asistoli husule gelebilir. 19 yaşinda bir koşucu $30 \mathrm{klm}$, koştuktan birkaç saat sonra had kalb genişlemesi belirtileriyle ölmüştür (Chauffard ve Ramond). Bu tipp had yetersizlik kronik miyokarditli hastalarda da görülür.

\section{H) GöGüS ANJINi (ANGINE DE POITRINE) :}

Anjin dö puatrin bir sendromdur. Bir çok kalb hastalıklarında görülür. Göğüs anjininden sonra şahıs ani olarak ölebilir. Kriz esnasında göğüs arkasında (Retrosternal) ve mide bölgesi üstünde (Epigastrique) şidetli ağrılar olur, bu ağrllar kola veya ekseriya omza akseder. Emotivitede görülen anguvaz ağrılarından çok daha șiddetli sıkıntı ve ağrı olur. Krizler birkaç saniye, umumiyetle bir kaç dakika sürer. Kriz esnasında birden yere düşüp ölünebilir. Bazan kriz geçer, şahıs kendini iyi hisseder. Yatağına yatırılır. Bir müddet sonra yatakta ölü bulunur.

Anjin dö puvatrinli şahıslarn bir çoğunda koroner lezyonları bulunur. Otopside anjinin hakiki sebebi tâyin edilir. Bu şahıslar kalbin ani durmasıyla ölürler. Bazılarnnda ölümden önce fibrillasyon olur. Fibrillation koroner damar tıkanmasının belirtilerindendir.

Anjin krizleri koroner hastalı̆̆ı olmayanlarda da görülür. Ağır kalb veya aort affeksiyonlan anjin de puvatrin yapabilir. Bu şahıslarda da ani ölüm nadir değildir. Bunlarda ölüm ekseriya aort yırtılması, had akciğer ödemi sebebiyle olur. Kalb ve damarlarında lezyon olmayan şahıslarda göğuis anjini sebebiyle ansızın ölüm olmaz. Bazı tip anjin krizleri, hakiki kriz olmayıp aldatıcı krizlerdir.

\section{III - ENDOKARD ,HASTALIKLARINDA ANSIZIN ÖL ÜM :}

Endokardit (Endocardite) :

Kalbin iç yüzünü ve kapakcıklarını örten ince parlak bir zar 
olan endokardın iltihabına endokardit ismi verilir. Valvül yüzlerini döşeyen endokarditler en çok görülenlerdir. Endokarditlerde ölüm, trombüs husulii ile veya valvüllerde stenoz, yetersizliğin tevlit ettiği ihtilâtlarla husule gelir. Otopside miyokardit, aortit v.s. gibi diğer bulgularda görülebilir.

Endokarditis șekilleri :

1) Endocarditis verrucosa (Romatizmal Endokardit, basit endokardit).

2) Tromboendokarditis ulceroza (Akut bakteriyel endokar+ dit).

3) Subakut bakteriyel Endokardit (Endocarditis lenta, Trombo endokarditis ülseroza lenta).

4) Tromboendokarditis fitizika.

Endokardit sonuçlan ve kalpte yaptığı değişiklikler :

1) Aort stenozu. 2) Aort yetersizliği. 3) Mitral stenozu. 4) Mitral yetersizliği. 5) Triküspid stenozu. 6) Triküspid yetersizliği. 7) Pulmonalis stenozu. 8) Kalb hipertrofisi. 9) Kalb dilatasyonu.

IV - KALB TÜMÖR KIST HIDATİK VE YABANCI CISIMLERI SEBEBIYLE ANSIZ IN ÖL ÜM :

Bunlar nadir görülen ansızın ölümlerdir. Lefas'in bir vak'asında yüzeyel bir anjiyom (damar uru) kopup perikard içine kanama yapmak suretiyle ansızın ölüme sebep olmuștur. Pediküllü bir endokard tümörü ölüme kadar gizli kalabilir. Ölüm kistin basincı ile fonksiyonel olarak veya kalb orifislerinden birinin tıkanması veya koroner sıkıșması neticesi eksito-motor iletim'in yapılamaması kistin yırtılması ve emboli sebebiyle olabilir.

Kistin yırtılması anaflaksi yapmak suretiyle de ansızın ölüm tevlit edebilir. Kist anevrizma husulii ve bunun yırtılmasıly da birden ölüm yapabilir. Yabancı bir cismin kalbe gitmesiyle ani ölüm nadirdir. Bir adamın kalbinde iğne bulunmuștur. Bu iğnenin vücuda ne zaman battığı nasıl kalbe geldiği tesbit olunamamıştır (Schwarzwald). 
V-KALB ANOMALILERI:

a) İki kulakcık arasında bulunan deliğin (Foramen Ovale) açık kalması sebebiyle ansızın ölüm olabilir. Bazan bu açıklık çok büyük olur, ve kulakcıklar arası septum kaybolur (Cor Trilloculare biventriculorum).

b) Bazan kalb karıncıkları arasında bir açıklık bulunur. Kalb 3 göz halini alır (Cor Trilloculare biatrium). Ekseriya açıklık membranöz kısımdadır. Bu durum Roger hastalığını meydana getirir. Anî ölüm olabilir.

c) Diğer Anomaliler : Kalb büyük damarları yerleri ve şekilleri kalbin normal yerinde olmaması görülebilir. Bu hallerde de ansızin ölüm görülmesi mümkündür.

\section{VI - KALB YIRTILMALARI RÜPTÜR (R UPTURE) :}

Kalb yirtılmasmın enfarktüs, anevrizma, myokard hastalıklarında olanları anlatıldı. Bundan başka kalbin büyüyerek cidarının incelmesi veya kalb adelesinin yağlanarak mukavemetini kaybetmesi veya kalb damarlarmin iltihabı dolayısiyle kalb adalesinin beslenemiyerek zayiflaması yurtılmaya sebep olabilir. Kalb yırtılması daha ziyade kalbin ön cidarında sol karıncıkta olur. Ihtiyarlarda ve erkeklerde daha çok görülür. Kalb yırtılmasına, yukarıda bahsettigimiziz, bazı hastalıklar bulunmak şartı ile heyecan, kuvvetli bir hareket sebep olabildiği gibi, bazan da hiç sebebsiz olarak bu hal vukua gelebilir. Kalbde husule gelen yurtık kafi derecede büyük ise șahıs birden, yldırımla vurulmuş gibi yere yıkılarak ölür. Șayet yırtık küçük ise şahıs yarım ilâ bir saat daha yaşayabilir. Bu müddet zarfında yapılan ameliyat șahsın hayatını kurtarbilir.

ÖZET : Bu etüdde kalb hastalığı sebebile husule gelen otopsi yapılmış 22 ansızın ölüm vakasının özellikleri Adlî Tıp bakımından önemi belirtildi. Ansızın ölüm yapan kalb hastalıkları incelendi. 


\section{LITERAT UR}

(1) Arondel E. Ollivier J: Infarctus du myocarde et angine de poitrine d'origine traumatique. Ann. Méd. Lég. Paris. 1963. No. 1. P. 57,

(2) Balthazard V : Précis de de Medecine Legale. Bailliere. Paris. 1935. $624 \mathrm{~S}$.

(3) Bon Henri : La mort et ses problemes, 1947. Paris. 286 sayfa.

(4) Bonita J. and Charles M. Petty s : Sudden naturel death among automobile drivers. J. For. Scl. 1962 . Vol. 7. No. 3. P, 274,

(5) Brouardel P : La mort Subite. Baillere. Paris. 1895. 450 sayfa.

(6) Borton J. F, Zawadzki E. S: The Coronary aneursm : J. For. Sci. 1982. Vol. 7. No. 4. P. 474.

(7) Chaumont A, Marcoułk F. Mehl J : Hemopéricard traumatique et Hemopericarde spontané. Ann. Med. Leg. Paris. 1963, No. 1, P. 63.

(8) Clausnitzer k, Trube, Becker: Granulomatöse Riesenzellen myokarditis als plötliche todesursache. Deut, zeit. Ger. Med. 1959 Band 48. Hett 4. P. 369 .

(9) Colin Corby : Isolated myocarditis as a cause of sudden obscure deat Med. Sci. and the Law. Londra. 1960, No. 1 P. 14.

(10) Derobert L, Quchaud $L$ : Le rôle de lemotion dans la mort Subite des Sujets de Cardiophathie. Ann. Méd. Lég. Paris. 1959, No. 4. P. 403.

(11) Derobert $\mathrm{L}$, Vacher J : Emotion et Infarctus du myocarde. Ann. Méd. Lég. Paris. 1953, No. 5. P. 249.

(12) Desruelles $\mathrm{J}$ : Les Lésions anatomiques du coeur polmonaire Chronnique Ann. Méd. Lég. Paris. 1959. No. 1. P. 57.

(13) Deumie M, Planques J, Fabre J : Mort par embolie dans l'aorte abdominal Thronbus organisé de la pointe du ventricule Gouche. Ann. Méd. Lég. Paris. 1957, No. 4. P. 207. 
(14) Fiorentini $H$. et Gras $A$ : Un cas de rupture non traumatique du Coeur diagnostic autopsique aprés exhumation. Ann. Méd. Lég. Paris. 1959 , No. 4, P. 360 .

(15) Fiorentini et Gras A : Diagnostic d'affection coronarienne sur le cadavre exhumé quatre mais et demi aprés la mort. Ann. Méd. Lég. 1957, No. 4, P. 218.

(16) Glaister John: Medical jurisprudence and Toxicology. 1962, 720 sayfa.

(17) Gordon L, Turner T, Price W : Medical jurisprudence. Londra. 1953. 944 sayfa.

(18) Gradwohl R. B. H : Legal Medicine. 1954 St. 1098 sayfa.

(19) Keith Simpson : Forensic Medicine. 1961. Londra. 355 sayfa.

(20) Lacassagne A et Martin E : Precis de Medecine Legale Masson. Paris. 1921. 752 seyfa.

(21) Laves i $W$ : Der Plötzliche Herztod im Strabenverkehr Untersuchun ger. Deut. Zeit. Gev. Med. Münih. 1958. Band. 47, Heft. 3, P, 303,

(22) Macrez C: Definition et estimation de l'etat anterieur en expertis Cardiolojique. Ann. Méd. Lég. Paris 1960, No. 4, P. 307.

(23) Martin E : Precis de Medecine Legale. 1950 Doin Paris. 756 sayfa.

(24) Merlen J. F. : La relation de cause à effets entre le coeur pulmonaire Cronique et l'oedeme aigu pumon. Ann. Méd. Lég. Paris. 1959, No. 1, P. 60 .

(25) Muller M, Muller B. H, Bar C : Les Sommations émotives. Ann. Méd. Lég. Paris. 1962, No. 5, P. 487.

(26) Ollivier H. et Babis G : Considerations a Propos d'un cas de mort Subite par infarctus du myocarde survenu aprés décharge électirique. Ann. Méd. Lég. Paris. 1956, No. 3. P. 136.

(27) Timperman $J$ : Un cas de myocardite aigue ayant entraine en quelques heures la mort d'un homme de vingt_cinq ans. Ann. Méd. Lég. Paris. 1960, No. 3, P. 283.

(28) Thomas A, Gonzales, Morgan Vance : Legal Medecin and toxicology. New-York 1948,754 sayfa.

(29) Thomas A, Gonzales Ch, Umberger J : Legal medecine Pathology and texicology. New - York. 1954, 1349 sayfa. 
(30) Simonin O: Medecine legal judiciare. 1955 Maloin, 1054 sayfa.

(31) Sydney Smith, Keit Simpson: Taylor's principles and practic of Medicial jirusprudence cilt 1. 1956, 626 sayfa. Cilt II. 1957. 647 sayfa.

(32) Willard Aronson and Thomas Pharmakis: The use of Suciinic dehydrogenase Stain in the autopsy diagnosis of carly acute myocardial infarction. J. For. Sci. New.York. 1962. Vol. 7. No. 2, P, 140,

(33) Vibert $\mathrm{Ch}$ : Medecine Legale. Masson. Paris. 1916. 960 sayfa. 